\title{
The use of immunogold-silver staining to study antigen variation and bacterial entry into eukaryotic cells by conventional light microscopy
}

\author{
J. P. M. VAN PUTTEN, * CARLA T. P. HOPMAN and J. F. L. WEEL
}

Department of Medical Microbiology, University of Amsterdam, Meibergdreef 15, 1105 AZ Amsterdam, The Netherlands

Summary. Immunogold-silver staining is a sensitive staining technique that enables the visualisation of the presence of individual antigens by conventional light microscopy. The application of this method to detect the antigenic heterogeneity of bacterial surface components and also the localisation of intracellular or extracellular bacteria is described. The latter application involved selective immuno-silver staining of the extracellular bacteria and counterstaining of the intracellular bacteria and the eukaryotic cells by crystal violet. The efficacy of the assay was confirmed by transmission electronmicroscopy of the silver-stained specimens. Immunogold-silver staining was shown to be useful for studying bacterial antigen variation and the uptake of bacteria by eukaryotic cells.

\section{Introduction}

Immunogold-silver staining (IGSS) is a sensitive immunological staining technique in which antibodies bound to specific antigens are marked with a gold probe, and silver is precipitated on to the gold spheres. ${ }^{1}$ The method is being employed increasingly for the demonstration of antigens on intact eukaryotic cells, ${ }^{2}$ in tissue sections ${ }^{3,4}$ and also in immunoblotting. ${ }^{5}$ In the field of microbiology, the phenotypic variation of surface-exposed antigens and the uptake of bacteria by both professional and non-professional phagocytes are important aspects of studies on the pathogenesis of bacterial infections. In this report, we describe two applications of the silver staining technique which may be of great value in these areas of research. One application is based upon the extreme sensitivity of IGSS that allows visualisation by light microscopy of single epitopes on individual bacteria. Therefore, IGSS can be used to identify bacteria on the basis of their antigenic properties and it can be applied to studies of the heterogeneity and immuno-accessibility of antigens among bacteria of a single strain by conventional light microscopy. The same technique can also be adapted to study bacterial entry into mammalian cells. In this

Received 20 Nov. 1989; accepted 1 March 1990.

* Present address to be used for correspondence: Dr J. P. M. van Putten, Max-Planck-Institut für Biologie, Abt. Infektionsbiologie, Spemannstr. 34 D-7400 Tübingen, FRG. application, based on the impermeability of the eukaryotic plasma membrane to antibodies and the gold-labelled conjugate, extracellular bacteria are selectively immuno-silver stained and intracellular bacteria and eukaryotic cells are counterstained. Both methods have been developed in studies with Neisseria gonorrhoeae, which has a high frequency of antigen variation and a capacity to enter human epithelial cells.

\section{Materials and methods}

\section{Bacterial strains and culture conditions}

$N$. gonorrhoeae strain 830563 was isolated from a patient with disseminated gonococcal infection; 12 other strains were primary isolates from patients with local gonococcal infection (AMC/OLVG, Amsterdam). Strains of commensal Neisseria spp. (N. mucosa, $N$. lactamica) were obtained from the Netherlands Reference Laboratory for Bacterial Meningitis, situated in our department. The strains were grown for $16 \mathrm{~h}$ on GC Medium Base (Difco) containing Vitox (Oxoid) $1 \%$ in a $\mathrm{CO}_{2}$-incubator $\left(37^{\circ} \mathrm{C}, \mathrm{CO}_{2} 5 \%\right)$.

\section{Cell culture}

Chang conjunctiva epithelial cells (Flow Laboratories, Irvine, Ayrshire), HeLa cells (Department of Virology, University of Amsterdam) and HEC-1B cells (ATCC HTB 113) were grown on $12 \mathrm{~mm}$ circular coverslips in a 24-well $\left(2 \mathrm{~cm}^{2}\right.$ each) multidish (Nunclon, Kamstrup, Roskilde, Denmark) in Dulbecco's Modified Eagle's Medium supplemented with fetal bovine serum (Flow 
Laboratories) $5 \%$ at $37^{\circ} \mathrm{C}$ in a humidified atmosphere of $\mathrm{CO}_{2} 5 \%$ in air. Primary cultures of human corneal epithelial cells were obtained as previously described, ${ }^{6}$ except that the corneal explants were allowed to adhere to the coverslips to enable outgrowth of the epithelium on to the glass surface.

\section{Infection of the epithelial cells}

The bacteria were suspended in $5 \mathrm{ml}$ of Dulbecco's phosphate-buffered saline, $\mathrm{pH} 7 \cdot 4$ (PBS) to a concentration of $10^{8} \mathrm{cfu} / \mathrm{ml}$ and $50 \mu \mathrm{l}$ of this suspension were added to each cup of the 24-well tissue culture plate. After $3 \mathrm{~h}$ $\left(37^{\circ} \mathrm{C}\right)$, unattached micro-organisms were removed by washing the cells three times with PBS. Fresh medium was added and the cells were incubated for up to $16 \mathrm{~h}$. At appropriate times, the medium was discarded and the cells were washed three times with PBS, fixed in PBS containing glutaraldehyde (GA) $0.1 \%$ and paraformaldehyde (PFA) $1 \%$ for $30 \mathrm{~min}$ at $20^{\circ} \mathrm{C}$, and stored in $50 \mathrm{~mm}$ Tris- $\mathrm{HCl}$ buffer, $\mathrm{pH} 7 \cdot 4$.

\section{Immunogold-silver staining}

The IGSS procedure is outlined in the table. Coverslips coated with bacteria and air-dried, or carrying infected epithelial cells, were fixed and incubated with an appropriate dilution of antiserum in a 24-well tissue culture plate. After washing to remove unbound antibodies, gold-conjugated protein A (10-nm gold particles, prepared according to the method of Slot and Geuze ${ }^{7}$ ) (protein $\mathrm{A}-\mathrm{Au}$ ) was added to label the antibodies. After incubation with the gold probe, the specimens were washed and physical developer was added which resulted in reduction of silver ions and precipitation of silver on to the bound gold particles. The silver enhancement process was stopped by rinsing with water and the coverslips were stored at $4^{\circ} \mathrm{C}$ in Tris buffer.

The developer was essentially prepared as described by Danscher ${ }^{1}: 60 \mathrm{ml}$ of Acacia powder (BDH Chemicals, Poole) $25 \%$, cleared by centrifugation at $25000 \mathrm{~g}(\mathrm{lh}$, $\left.20^{\circ} \mathrm{C}\right)$ and $100000 \mathrm{~g}\left(1 \mathrm{~h}, 20^{\circ} \mathrm{C}\right)$ were mixed with $10 \mathrm{ml}$ of citrate buffer (citric acid monohydrate $25.5 \mathrm{~g}+$ sodium citrate dihydrate $23.5 \mathrm{~g} / 100 \mathrm{ml}$ of water) and $15 \mathrm{ml}$ of reducing agent (hydroxyquinone $5.66 \mathrm{~g} / 100 \mathrm{ml}$ of water). Immediately before use $15 \mathrm{ml}$ of silver ion solution (silver lactate $0.11 \mathrm{~g}$ in $15 \mathrm{ml}$ of water) were added and the solution was protected from light. The mixture was freshly prepared but stock solutions of Acacia powder can be kept at $-20^{\circ} \mathrm{C}$ for at least one year. Several blocking steps were included in the protocol to reduce non-specific binding of the antibodies and the gold probe (table). When isolated bacteria were probed, the coverslips were pre-coated with tissue culture medium $(2 \mathrm{~h}$, $37^{\circ} \mathrm{C}$ ) to reduce background staining.

Analysis of the immuno-accessibility of antigenic determinants on isolated bacteria was performed with bacteria in suspension, because fixation and air-drying of the bacteria on coverslips might influence antigen
Table. IGSS procedure for extracellular bacteria

1. Fixation: PBS + GA $0 \cdot 1 \%+$ PFA $1 \% ; 30 \mathrm{~min}, 20^{\circ} \mathrm{C}$

2. Wash: $50 \mathrm{~mm}$ Tris- $\mathrm{HCl}, \mathrm{pH} 7.4 ; 20^{\circ} \mathrm{C}, 30 \mathrm{~min}$

3. Wash: PBS $5 \mathrm{~min}, 20^{\circ} \mathrm{C}$

4. Blocking solution: $100 \mu \mathrm{l}$ PBST + BSA $3 \% ; 15 \mathrm{~min}$, $37^{\circ} \mathrm{C}$

5. Antiserum : $100 \mu \mathrm{l}$ antiserum in PBST + BSA $0.5 \% ; 30$ $\min , 37^{\circ} \mathrm{C}$

6. Wash: PBST; $3 \times 5 \mathrm{~min}, 20^{\circ} \mathrm{C}$

7. Blocking solution: $100 \mu \mathrm{l}$ PBST $+\mathrm{BSA} 3 \% ; 30 \mathrm{~min}, 37^{\circ} \mathrm{C}$

8. Conjugate: $100 \mu \mathrm{l}$ protein A-Au in PBST + BSA $0.5 \%, 30$ $\min , 37^{\circ} \mathrm{C}$

9. Wash: PBST; $2 \times 5 \mathrm{~min}, 20^{\circ} \mathrm{C}$

10. Wash: distilled water; $2 \times 5 \mathrm{~min}, 20^{\circ} \mathrm{C}$

11. Developer: $45 \mathrm{~min}, 20^{\circ} \mathrm{C}$, in the dark

12. Wash: distilled water; $2 \times 5 \mathrm{~min}, 20^{\circ} \mathrm{C}$

13. Storage: $50 \mathrm{~mm}$ Tris- $\mathrm{HCl}, \mathrm{pH} 7 \cdot 4 ; 4^{\circ} \mathrm{C}$

PBST, PBS + Tween $200.05 \%$; BSA, bovine serum albumin, $\gamma$-globulin free (Sigma A-7030); GA, glutaraldehyde; PFA, paraformaldehyde.

exposure. The suspended bacteria $\left(5 \times 10^{6} \mathrm{cfu} / \mathrm{ml}\right.$ in tissue-culture medium) were incubated with the appropriate dilution of antiserum $\left(30 \mathrm{~min}, 37^{\circ} \mathrm{C}\right)$ in $1-\mathrm{ml}$ Eppendorf vials. After centrifugation at $10000 \mathrm{~g}$ for 3 min to remove unbound antibodies, the bacteria were resuspended in a solution of protein A-Au. After removal of the unbound gold particles by centrifugation at $10000 \mathrm{~g}$ for $3 \mathrm{~min}$, the cells were allowed to dry on pre-coated coverslips, fixed and silver stained.

\section{Immunological reagents}

The gonococci were stained with either monoclonal antibodies (MAbs) (produced as described by Tam et $a l^{8}$ ) or polyclonal sera. The specificity of the antibodies was determined by gel-immuno-radio-assay. ${ }^{9}$ The polyclonal sera were obtained from The Netherlands Reference Laboratory for Bacterial Meningitis. They were raised by immunising rabbits with the meningococcal reference strains $2396(\mathrm{NG}: 2 \mathrm{c}: \mathrm{P} 1.2: \mathrm{L6})$ and $\mathrm{M} 990$ (B:6:P1.6:L6). In staining the commensal Neisseria spp., a mixture of polyclonal rabbit antisera raised against $N$. meningitidis group X (reference strain) and strain M981 (B:4:P1,-:L4) was used. Although the polyclonal sera were raised against heterologous strains, they contained sufficient cross-reacting antibodies for silver staining of all cells of the test strains.

\section{Counterstaining}

The coverslips with the IGSS specimens were counterstained overnight with $2 \mathrm{ml}$ of crystal violet (Bactocrystal violet C.I. 42555 ; Difco) $0.007 \%$ in distilled water. The stained specimens were stable in this solution for several months. 


\section{Light microscopy}

The coverslips were examined by inverting them on to distilled water on a microscope slide. A standard Olympus transmitted light microscope (model BH-2) with a $100 \times$ objective lens was used to view the specimens. Micrographs were made with an Olympus OM-2 camera.

\section{Electron microscopy}

IGSS specimens were prepared for electronmicroscopy as previously described. ${ }^{10}$ The sections were viewed with a Philips EM 300 electronmicroscope at $60 \mathrm{kV}$.

\section{Results}

\section{IGSS of isolated bacteria}

The usefulness of IGSS in visualising bacterial antigens by light microscopy was examined by incubating gonococci ( $N$. gonorrhoeae strain 830563) with a major outer-membrane-protein (pII)-specific MAb and protein A-Au, and then coating the specimen on to a coverslip. This procedure resulted in faint red staining of the bacteria. However, when silver was precipitated on to the gold grains, intense black staining of the gonococci was obtained that could easily be identified by light microscopy even at low magnification $(200 \times)$ (fig. 1). There was no immunostaining when a MAb with a different specificity was used, suggesting that there had been specific marking of the probed antigens. Interestingly, poststaining of the specimen with aqueous fuchsin $0.5 \%$

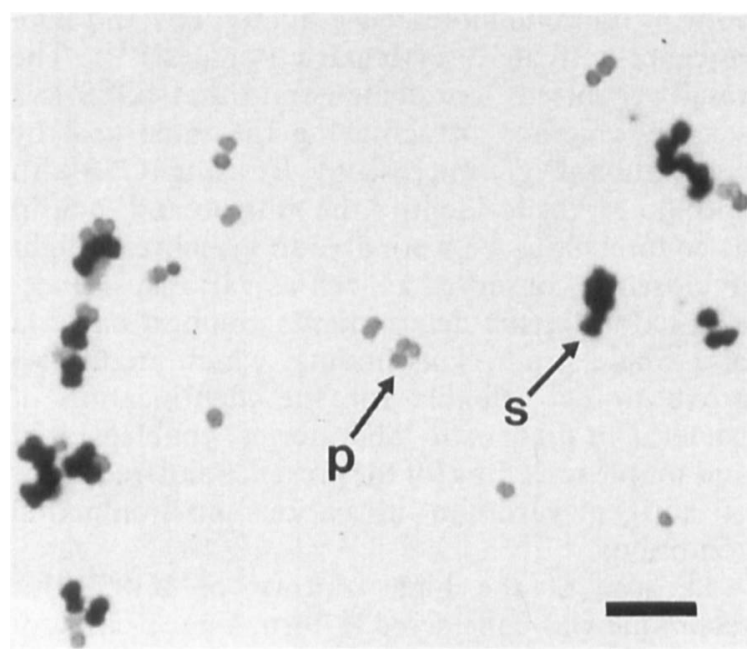

Fig. 1. Light micrograph of gonococci after IGSS with a PIIspecific MAb and counterstaining with fuchsin; some bacteria were immuno-stained (black-brown, i.e., dark; s) whereas another subpopulation was stained pink (i.e., pale; p). (Bar, $5 \mu \mathrm{m})$. revealed that the silver staining was restricted to a subset of the bacterial population (fig. 1), demonstrating a variable surface expression of the probed pII epitope among the bacteria. When a MAb directed against a lipo-oligosaccharide (LOS) epitope was used to probe the cells, similar results were obtained, indicating that this LOS epitope also was not uniformly expressed among the bacterial population. LOS and pII antigens of $N$. gonorrhoeae are known to be subject to phenotypic variation. ${ }^{11,12}$ The selective immunostaining in the bacterial population was not seen with MAbs or polyclonal antisera that recognised conserved antigenic determinants on the bacteria. These findings indicate that IGSS can be applied to identify bacteria on the basis of their antigenic properties and to demonstrate antigen variation by light microscopy.

\section{The IGSS-crystal violet assay}

The successful silver staining of bacterial antigens made it possible to test IGSS as a first step in an immunocytochemical assay to enable localisation of bacteria inside or outside eukaryotic cells by light microscopy. Chang conjunctiva epithelial cells were infected with $N$. gonorrhoeae strain 830563 for various periods, fixed, and stained by the IGSS procedure with a polyclonal antiserum that had been shown to react with the entire test population of bacteria. Light microscopy of the IGSS-stained specimens revealed numerous cell-associated diplococci that were stained intensely black-brown on eukaryotic cells that showed no background staining when the procedure in the table was followed. Since both intact and GA-PFA fixed cells are impermeable to antibodies and conjugate, the IGSS-stained bacteria were thought to represent adherent extracellular gonococci.

To visualise the non-immuno-stained intracellular bacteria and the eukaryotic cells, it was necessary to use a counterstain. For satisfactory staining, the $\mathrm{pH}$ of the IGSS-treated specimen, which was very low after incubation with the developer, had to be raised by rinsing the cells with Tris-buffer $(\mathrm{pH} \mathrm{7.4)}$ for at least $1 \mathrm{~h}$. Different stains were tested for their capacity to stain the intracellular bacteria. Loeffler's methylene blue, fuchsin, Giemsa, and methyl greenpyronin showed insufficient staining probably because of poor diffusion of the dye into the cells. However, counterstaining with a low concentration of crystal violet for at least $15 \mathrm{~h}$ was satisfactory. By light microscopy the bacteria appeared as deep violet diplococci with faint violet cytoplasm of the eukaryotic cells as background (fig. $2 a$ ). The violet 

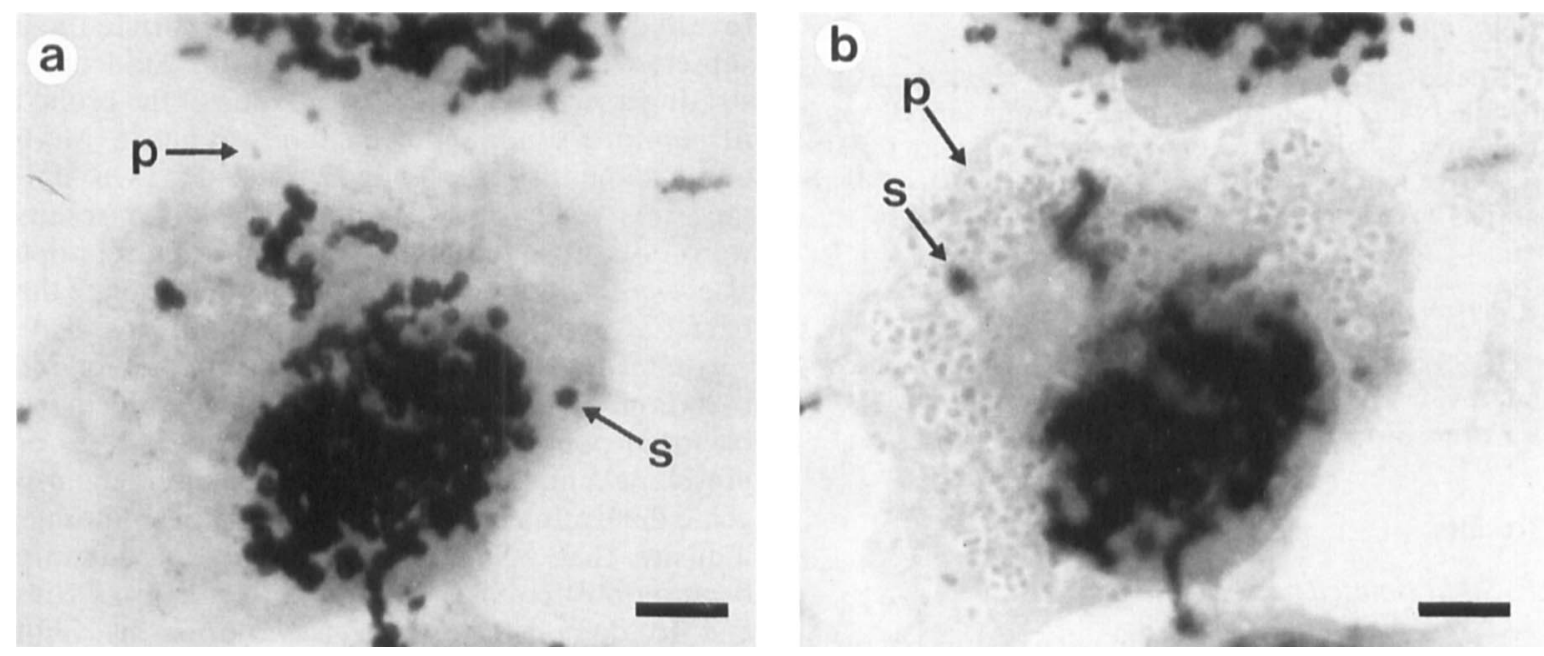

Fig. 2. Light micrograph of infected epithelial cells $(16 \mathrm{~h})$ atter IGSS of extracellular bacteria (black-brown, i.e., dark; s) and counterstaining of intracellular bacteria and eukaryotic cells with crystal violet (i.e., pink; p); focused (a) on the adherent bacteria, (b) on the intracellular bacteria, which appear to be in vacuoles within the cells. (Bars, $15 \mu \mathrm{m}$ ).

bacteria were in focus at a different level from the silver stained bacteria and often seemed to be inside a vacuole, suggesting their intracellular localisation (cf. figs $2 \mathrm{a}$ and b). This impression was further strengthened by finding that the number of violet bacteria increased with the duration of the infection. In the early infection period $(1-3 \mathrm{~h})$, very few deep violet bacteria were observed, but after $16 \mathrm{~h}$, as many as 50 violet bacteria/cell could be seen. Conclusive evidence for the efficacy of the method in differentiating between adherent and intracellular bacteria was obtained by electronmicroscopy of the IGSS-treated specimen; all the extracellular bacteria had several to many gold-silver particles on their membranes, whereas the intracellular bacteria did not contain any immunolabel (fig. 3).

The more general applicability of the IGSScrystal violet method was demonstrated by screening several epithelial cell lines (HeLa, HEC-1B) and primary cultures of human corneal epithelial cells for extra- and intra-cellular bacteria after infection with 12 gonococcal and two commensal Neisseria strains. In all cell types, it was easy to locate the bacteria inside or outside the cells, although in HeLa cells the intracellular bacteria were sometimes less marked because of the rather intense violet staining of these cells. Fig. 4 shows the localisation of the bacteria in human corneal epithelial cells.

\section{Discussion}

Many bacteria, including the pathogenic neisseriae, show intrastrain variability with respect to the antigens that they expose on their surface. ${ }^{11,13}$ This phenotypic variation may arise from antigenic heterogeneity or from a variable immuno-accessibility of the antigens. Knowledge of this phenomenon is important for improved understanding of the pathogenesis of infections and for vaccine development because such variation might serve as a means of escaping the host immune response or as an adaptation to the host cell environment. ${ }^{12}$ Sophisticated techniques for determining phenotypic variation amongst bacteria in a population of a single strain include: immuno-electronmicroscopy ${ }^{14}$ immunofluorescence microscopy and fluorescence-activated cytometric analysis. ${ }^{11}$ The results reported here demonstrate that IGSS is a sensitive method of achieving the same goal by conventional light microscopy. By using IGSS with specific MAbs to identify the antigen and fuchsin as counterstain, we were able to visualise by light microscopy conserved as well as variable surfaceexposed antigenic determinants amongst bacteria of a single strain. This finding, which might also prove to be valuable for the identification of bacteria in diagnostic laboratories, enabled rapid and simple screening for the presence and frequency of antigen variation in various environmental conditions.

Because of the high contrast of IGSS, this technique was considered to form a good basis for a simple assay to distinguish between adherent and internalised bacteria in studies on the uptake of bacteria into eukaryotic cells. For the development of a reliable assay several conditions must be achieved: (i) the antiserum should recognise all the 


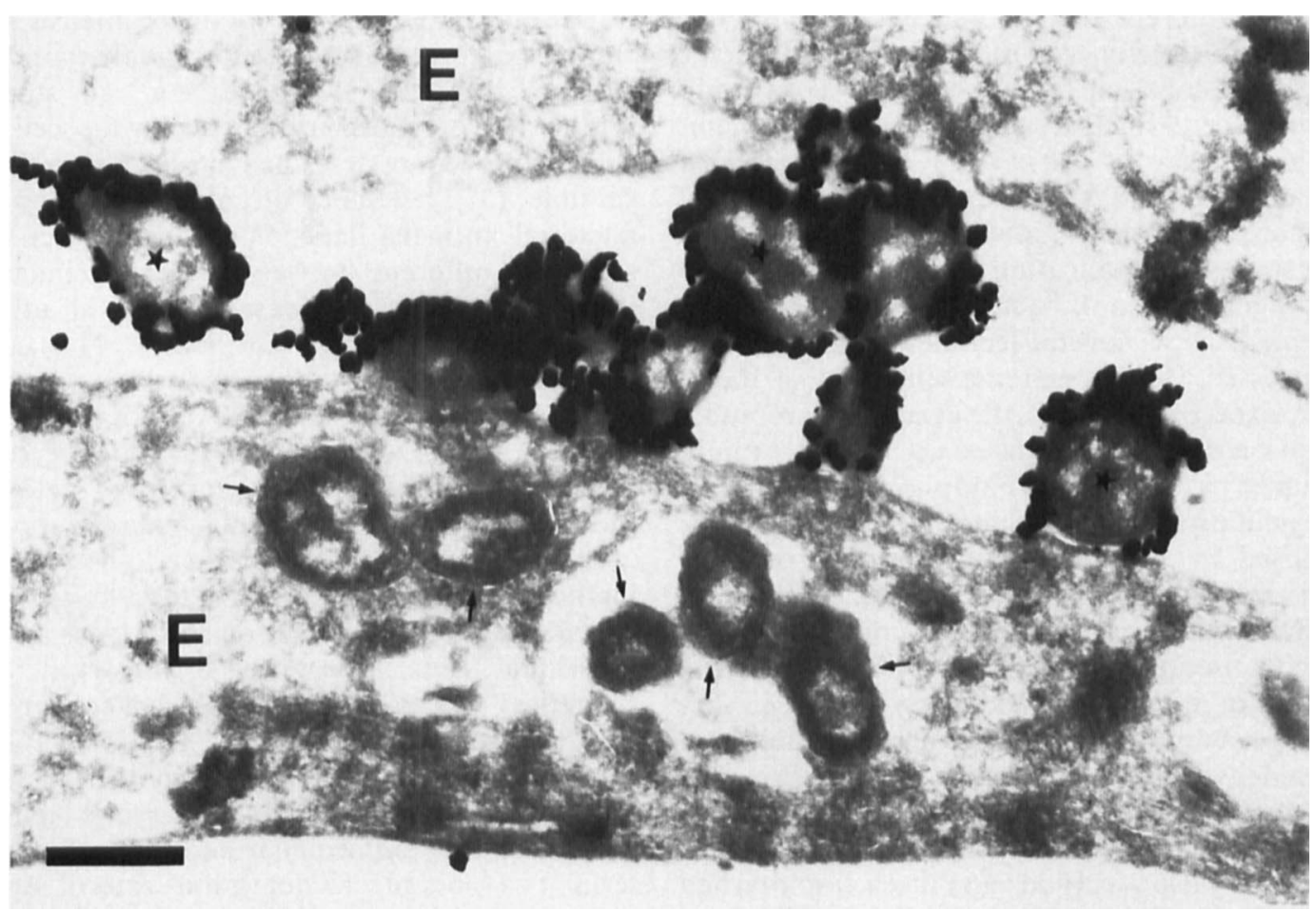

Fig. 3. Transmission electronmicrograph of IGSS-stained infected epithelial (E) cells $(16 \mathrm{~h})$. All the extracellular bacteria (some indicated by ${ }^{*}$ ) have silver particles on their membranes; intracellular bacteria $(\rightarrow)$ are not immunolabelled. (Bar, $\left.0 \cdot 75 \mu \mathrm{m}\right)$.

extracellular bacteria with a minimum of nonspecific binding to the eukaryotic cells; (ii) the host cell membrane should remain impermeable to the antibodies and the conjugate; (iii) the morphology of the cells should be preserved to allow localisation

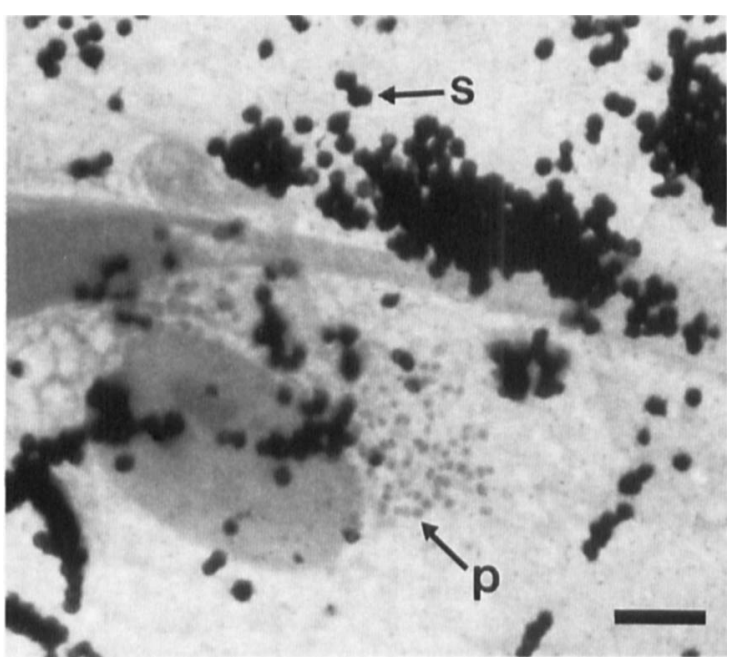

Fig. 4. Light micrograph of infected corneal epithelial cells $(18 \mathrm{~h})$ after staining by IGSS-crystal violet showing immunostained (black; s) adherent bacteria and violet-stained (pale; p) intracellular bacteria. (Bar, $15 \mu \mathrm{m}$ ). of the bacteria; and (iv) the counterstain should diffuse freely into the cells, and should preferentially stain the intracellular bacteria. Our observations by light microscopy, confirmed by transmission electronmicroscopy, indicate that the combined use of IGSS to stain the adherent bacteria and crystal violet to stain the intracellular bacteria fulfils these requirements.

Hitherto various methodologies have been used to differentiate between extracellular and intracellular bacteria. These include plate counting of intracellular bacteria, ${ }^{15,16}$ the selective incorporation of radiolabel ${ }^{17}$ and fluorescence microscopy. ${ }^{18-20}$ The first two methods are inappropriate for studying the bacterial entry process because they estimate intracellular survival rather than the internalisation of bacteria; furthermore, they provide no information about the interaction of bacteria and individual cells. The fluorescence microscopy assays are based on the selective fluorescence of extracellular and intracellular bacteria. In our experience, these methods were unsatisfactory because of dilution of the label when the bacteria began to multiply during the infection (fluorescence quenching method ${ }^{18}$ ), non-specific staining (fluorescence incident light microscopy/ 
Nomarski differential interference contrast microscopy), ${ }^{20}$ or interference of the counterstain with the fluorescence-label on the adherent bacteria (indirect fluorescent-antibody assay). ${ }^{19}$ These problems are overcome by the use of the IGSS-crystal violet method which has the additional advantage of using conventional light microscopy.

For successful application of the IGSS technique in the identification of bacterial antigens by direct light microscopy, several technical points need to be addressed. (1) The extreme sensitivity of IGSS, which exceeds that of the classical immunoperoxidase staining by a factor up to $200,,^{3,4}$ might be reduced by non-specific binding of the antiserum or the gold probe; this background staining can be minimised by including one or more 'blocking' steps in the staining procedure (table). (2) Fixation (e.g., air-drying) before immunostaining may interfere with the accessibility or preservation of the antigens, or with the permeability of the plasma membrane to antibodies and conjugate. Therefore, glutaraldehyde should be used with caution, because it damages membrane antigens, including epitopes on the gonococcal major outer-membrane protein $\mathrm{pI}^{10}$ (also Weel and van Putten, unpublished observations). This might result in sub-optimal IGSS when such antigens are probed. However, fixation is not required for IGSS; with a slightly modified IGSS procedure (replacement of PBST by tissue-culture medium and performing the whole

\section{REFERENCES}

1. Danscher G. Histochemical demonstration of heavy metals. A revised version of the sulphide silver method suitable for both light and electron microscopy. Histochemistry $1981 ; 71: 1-16$.

2. De Waele M, De Mey J, Renmans W, Labeur C, Reynaert $P$, van Camp B. Immunogold-silver staining of lymphocyte surface antigens on cells in suspension and in lymphnode cryostat sections. J Microsc 1986; 143: 151160.

3. Holgate CS, Jackson P, Cowen PN, Bird CC. Immunogoldsilver staining: a new method of immunostaining with enhanced sensitivity. $J$ Histochem Cytochem 1983; 31 : 938-944.

4. Springall DR, Hacker GW, Grimelius L, Polack JM. The potential of immunogold-silver staining method for paraffin sections. Histochemistry 1984; 81 : 603-608.

5. Brada D, Roth J, "Golden blot"-detection of polyclonal and monoclonal antibodies bound to antigens on nitrocellulose by protein A-gold complexes. Anal Biochem 1984; 142: 79-83.

6. Tjia KF, Van Putten JPM, Pels E, Zanen HC. The interaction between Neisseria gonorrhoeae and the human cornea in organ culture. An electron microscopic study. Graefes Arch Clin Exp Ophthalmol 1988; 226: 341-345. procedure at $37^{\circ} \mathrm{C}$ ), we obtained intense silverstained bacteria adherent to living eukaryotic cells. When fixation is desirable, e.g., to stop the interaction of bacteria and eukaryotic cells, the fixation procedure described has been proven to be suitable. (3) The choice of antibodies to label the bacterial antigens depends on the subject under study; to differentiate between extracellular and intracellular bacteria, it is essential that all adherent bacteria react with the antibodies. This can be achieved, as our results demonstrate, by using polyclonal antibodies or MAbs that recognise conserved epitopes. These antibodies are readily available and our polyclonal sera cross-reacted with the whole population of various Neisseria spp.

In conclusion, IGSS may prove to be a valuable method for identification of bacteria as well as for studying phenotypic variation of antigens amongst individual bacteria by virtue of its simplicity, its sensitivity and, particularly, its use of conventional light microscopy. Furthermore, the use of IGSS in combination with crystal violet enables studies on the entry of bacteria into eukaryotic cells. By quantitation of extracellular and intracellular bacteria it is possible to determine rate of uptake, differences in invasive properties between strains, and variation in susceptibility of host cells to bacterial entry.

This work was financially supported by the "Praeventiefonds" (grant 28-892).

7. Slot JW, Geuze HJ. A new method of preparing gold probes for multiple-labelling cytochemistry. Eur J Cell Biol $1985 ; 38$ : 87-93.

8. Tam MR, Buchanan TM, Sandstrom EG et al. Serological classification of Neisseria gonorrhoeae with monoclonal antibodies. Infect Immun 1982; 36: 1042-1053.

9. Poolman JT, Buchanan TM. Monoclonal antibody activity against native and denatured forms of gonococcal outer membrane proteins as detected by ultrathin, longitudinal slices of polyacrylamide gels. $J$ Immunol Methods $1984 ; 75: 265-274$.

10. Weel JFL, Van Putten JPM. Ultrastructural localization of gonococcal antigens in infected epithelial cells as visualized by post-embedding immuno-electron-microscopy. Microb Pathog 1988; 4: 213-222.

11. Apicella MA, Shero M, Jarvis GA, Griffiss JM, Mandrell RE, Schneider $H$. Phenotypic variation of antigen expression of the lipooligosaccharide of Neisseria gonorrhoeae. In: Poolman JT, Zanen HC, Meyer TF et al. (eds) Gonococci and meningococci. Dordrecht, Kluwer Academic Publishers. 1988: 477-483.

12. Meyer TF, Frosch M, Gibbs CP et al. Virulence functions and antigen variation in pathogenic Neisseriae. Antonie van Leeuwenhoek 1988; 54: 421-430.

13. Meyer TF, Van Putten JPM. Genetic mechanisms and biological implications of phase variation in pathogenic neisseriae. Clin Microbiol Rev 1989; 2: S139-S145. 
14. Apicella MA, Shero M, Jarvis GA, Griffiss JM, Mandrell RE, Schneider H. Phenotypic variation in epitope expression of the Neisseria gonorrhoeae lipooligosaccharide. Infect Immun 1987; 55: 1755-1761.

15. Thomas DW, Hill JC, Tyeryar FJ. Interaction of gonococci with phagocytic leukocytes from men and mice. Infect Immun 1973; 8: 98-104.

16. Finlay BB, Falkow $\mathrm{S}$. Comparison of the invasion strategies used by Salmonella cholerae-suis, Shigella flexneri and Yersinia enterocolitica to enter cultured animal cells: endosome acidification is not required for bacterial invasion or intracellular replication. Biochimie 1988; 70: $1089-1099$.

17. McCoubrey WK, Howard LV. Incorporation of $\left[{ }^{14} \mathrm{C}\right]-$ methionine by Yersinia enterocolitica after invasion of HeLa cells. Infect Immun 1981 ; 32: 956-959.

18. Hed J. The extinction of fluorescence by crystal violet and its use to differentiate between attached and ingested microorganisms in phagocytosis. FEMS Microbiol Lett 1977; $1: 357-361$.

19. Kihlstrom E. Infection of HeLa cells with Salmonella typhimurium 395 MS and MR 10 bacteria. Infect Immun $1977 ; 17: 290-295$.

20. Bukholm G, Johansen BV, Namork E, Lassen J. Bacterial adhesiveness and invasiveness in cell culture monolayer. Acta Pathol Microbiol Immunol Scand Sect B $1982 ; 90: 403-408$. 